\title{
The Rise and Consolidation of Islamic State: External Intervention and Sectarian Conflict
}

\section{Abdul Basir Yosufi}

\author{
Ministry of Interior, Islamic Republic of Afghanistan
}

\begin{abstract}
This research paper examines the extent to which both the United States (US) intervention in 2003 and sectarian conflict in Iraq and the region contributed to the rise and consolidation of the Islamic State (IS). It is argued that the US intervention contributed to the rise of IS by creating a strategic cause for mobilization of insurgency while insufficient counterinsurgency resources and doctrine, and the lack of a post-war plan enabled the insurgency to consolidate. Although the US adapted its strategy and deployed additional resources as part of the "surge," which succeeded in weakening of the insurgents significantly, the premature withdrawal of US troops allowed for a revival of the insurgency which eventually evolved into IS. The sectarian conflict in Iraq and the region further contributed to the rise and consolidation of IS by helping in proliferation of the group's underlying ideology, increasing funding opportunities for the insurgents and driving the Sunni communities to support the Islamic State.
\end{abstract}

Keywords: counterinsurgency, insurgency, Iraq, ISIS, Islamic State, sectarian conflict, US intervention.

\section{Introduction}

In August 2014, the Islamic State of Iraq and Syria (ISIS) stunned the world by capturing Iraq's second largest city, Mosul, sending shockwaves across the world. About 800 ISIS fighters routed an estimated 30,000 Iraqi Security Forces, who threw away their weapons and uniforms, and fled for safety. In a matter of weeks ISIS fighters had captured several other Sunni dominated provinces including Nineveh, Salahuddin, and parts of Diyala, reaching the outskirts of Iraqi capital, Baghdad. Even more shocking was the massacre of 1,700 Iraqi soldiers and the displacement of roughly half a million people who escaped the atroci- 
ties of the terrorist group in the wake of its sweeping advances. Shortly after taking Mosul, the group formally changed its name to the Islamic State, inviting all Muslims to immigrate to the newly founded Caliphate. The atrocities committed by the IS caused one of the most serious refugee and humanitarian crises since the end of World War II and the group is considered as one of the most serious threats to international security.

This paper addresses two parallel issues: How-and to what extent-did both the US intervention in 2003 and sectarian conflict contribute to the rise and consolidation of Islamic State? Using a case study methodology, the research focuses on abovementioned factors for the following three reasons. First, there is an academic and research gap regarding these two factors in Iraq's case. Many papers have been written on IS which discuss different aspects of the group and many politicians have blamed the US intervention and sectarian policies of Prime Minister Nouri al-Maliki of Iraq for the rise of the group. However, there is little systematic analysis in academic literature regarding these two factors and their contributing mechanism. Second, these two factors are considered the most important contributors to the rise and consolidation of IS. And third, research and analysis on these two factors could have significant policy implications not only in dealing with IS but also for future external interventions in the region.

\section{The US Intervention and the Rise of Insurgency}

The US intervention in Iraq and its aftermath contributed to the rise and strengthening of an insurgency that eventually evolved into IS. It could be argued that, in many ways, the fall of Saddam Hussain and his Ba'athist regime was inevitable and just a matter of time. He was one of the longest ruling dictators of modern times, who invaded two neighboring states, destroyed and impoverished his country in unnecessary confrontations with his neighbors and the West, and was not shy to use chemical weapons against his own people. He came from the Sunni community of Iraq, who make up about 20 percent of the Iraqi population, and persecuted the country's Shias and Kurds who constitute about 60-65 and 15-20 percent of Iraqi population respectively. He might have been overthrown by the Arab Spring as was the case with Mubarak, Qaddafi and Ben Ali or may have faced an insurgency like Bashar al-Assad in neighboring Syria. It will never be known, as is the case with all counterfactual incidents. However, it may be said with confidence that with him in power the world would not have witnessed a large scale Sunni insurgency which eventually evolved into Islamic State.

While al-Qaeda was a by-product of the Soviet invasion of Afghanistan, the rise of IS was facilitated by the US intervention in Iraq in 2003. The Soviet invasion, which lasted for a decade from 1979 to 1989, led to an Islamists-led insurgency, attracting thousands of Afghan and foreign fighters. The US and its Western allies supported the Afghan Mujahedeen against the Soviets by providing them money, arms and training through the Pakistani Inter-Services 
Intelligence (ISI). During this period, many Arab fighters, among them Osama Bin Laden, came to Afghanistan to take part in Jihad against the Soviet Union. When the Soviets withdrew from Afghanistan, many of these fighters returned to their countries to form or join radical groups to fight their governments. Using contacts and reputation built in Afghanistan, Osama Bin Laden founded AlQaeda in 1991 to wage a global war against the West.

Abu Musaab al-Zarqawi was one of the radicals who met with Bin Laden and his lieutenants in Afghanistan and ran a training camp in the western Afghanistan province of Herat. He returned to Iraq to found the radical movement, Jama 'at Tawhid Wal Jihad (the Group of Unity and Jihad) in 1999. This was the movement which continued to evolve into Al-Qaeda in Iraq (AQI), Islamic State in Iraq, Islamic State in Iraq and Syria (ISIS) and finally the Islamic State (IS). ${ }^{1}$

\section{The US Intervention as a Strategic Cause for Insurgents}

According to French counterinsurgency scholar, David Galula, the first prerequisite of a successful insurgency is the existence of a strategic cause that can attract a significant number of people. ${ }^{2}$ This is because the insurgent leaders have to find potential supporters among the population and convince them to actively or passively support the insurgency. For instance, the Soviet invasion of Afghanistan was an attractive strategic cause not only for the insurgents from within the country but also from around the Muslim world, from where many fighters joined the insurgency. In the same way, the US intervention in Iraq provided the insurgents with a strategic cause to attract fighters and funding. Insurgents' resources, power and capabilities were in no way comparable to those of the US, but they had a valuable intangible asset - the cause to fight foreign invasion - which helped them attract a significant number of supporters, fight and continue to evolve.

\section{The US Intervention and the Popularity; Zarqawi and His Group}

Although Jama'at Tawhid Wal Jihad group (the Group of Unity and Jihad) was founded in 1999, it was the 2003 US intervention in Iraq which provided the group and its leader Zarqawi the opportunity to lead a large scale insurgency with a strategic cause of fighting external invasion. The first time Zarqawi came to headlines was following the attacks on the Jordanian Embassy and the United Nation compound in Baghdad in August 2003. ${ }^{3}$ The group was initially

1 Mohammad-Mahmoud Ould Mohamedou, "ISIS and the Deceptive Rebooting of al Qaeda," GCSP Policy Paper 2014/5 (Geneva: GCSP, August 2014), accessed August 3, 2016, http://reliefweb.int/sites/reliefweb.int/files/resources/ISIS\%20and\%20the\%20 Deceptive\%20Rebooting\%20of\%20Al\%20Qaeda.pdf, 2.

2 David Galula, Counterinsurgency Warfare: Theory and Practice (Westport, Conn.: Greenwood Publishing Group, 2006), 17.

3 Ould Mohamedou, "ISIS and the Deceptive Rebooting of al Qaeda." 
founded to fight against the existing secular governments, but the cause was not attractive enough to mobilize a significant number of people.

As the insurgency gained momentum after the US 2003 intervention, so did Zarqawi's group's activities. Between 2003 and 2005 the group was responsible for 42 percent of all suicide bombings which made up the bulk of casualties. ${ }^{4}$ The First Battle of Falluja, where the insurgents showed stiff resistance and bled the world's strongest army, led to an increased public appeal and strength of Tawhid Wal-Jihad group in Iraq. In October 2004, al-Zarqawi pledged his allegiance to Osama Bin Laden, the leader of Al-Qaeda, and changed the name of the group to Tanzim Qaedat al-Jihad fi Bilad al-Rafidayn, or al-Qaeda in the Land of the Two Rivers, referred to as al-Qaeda in Iraq (AQI). The Second Battle of Falluja that began in early November 2004 and lasted for six weeks further added to the notoriety of al-Zarqawi and AQI. The battle was tactically won by the US military who took the city with more than 2000 casualties to the insurgents compared with only 70 US marines' casualties. However, the destruction of the city and the displacement of civilians provided a valuable propaganda tool for the rebels. ${ }^{5}$

Al-Zarqawi was killed in an American air strike on 7 June 2016, but AQI continued to fight and evolve. In October 2006, the AQI was joined by some other insurgent groups to form the Islamic State in Iraq (ISI). As the external intervention and sectarian conflict continued to fuel the insurgency, deceased leaders were replaced by others and the group continued to evolve. The table below shows evolution of the Islamic State overtime.

Table 1. The evolution of ISIS.

\begin{tabular}{|l|l|l|}
\hline Configuration & Period & Leader(s) \\
\hline Jama'at al Tawhid wal Jihad & Late 1999-17 October 2004 & Abu Mus'ab al Zargawi \\
\hline Al Qaeda fi Bilad al Rafidayn & $\begin{array}{l}\text { 17 October 2004-15 January } \\
2006\end{array}$ & $\begin{array}{l}\text { Abu Mus'ab al Zargawi } \\
\text { Abu Omar al Baghdadi }\end{array}$ \\
\hline $\begin{array}{l}\text { Majlis al Shura al } \\
\text { Mujahideen }\end{array}$ & $\begin{array}{l}15 \text { January 2006-15 October } \\
2006\end{array}$ & Abu Hamza al Muhajir \\
\hline Islamic State of Iraq & 15 October 2006-9 April 2013 & $\begin{array}{l}\text { Abu Hamza al Muhajir } \\
\text { Abu Ayyub al Masri } \\
\text { Abu Bakr al Baghdadi }\end{array}$ \\
\hline $\begin{array}{l}\text { Islamic State of Iraq and al } \\
\text { Shaam }\end{array}$ & $\begin{array}{l}\text { 15 October 2006-29 June } \\
\text { 2014 }\end{array}$ & Abu Bakr al Baghdadi \\
\hline The Islamic State & 29 June 2014-present & Abu Bakr al Baghdadi \\
\hline
\end{tabular}

Source: GCSP Policy Paper 2014/5 - August 2014

4 Patrick Cockburn, The Rise of Islamic State: ISIS and the New Sunni Revolution (New York: Verso Books, 2015), 28.

5 Ibid., 34-35. 


\section{Weakness of the Counterinsurgents, an Opportunity for Insurgency to Expand}

Another prerequisite for a successful insurgency, according to Galula, is the weakness of counterinsurgent or government forces. ${ }^{6}$ The weakness could be political such as weak legitimacy, administrative such as the inability to provide good governance and jobs, or military weakness such as insufficient resources and troops. Despite the US intervention providing a strategic cause for the insurgency, the rise of IS was not inevitable and a well-planned and resourced COIN campaign could have defeated the rebels. However there were political, military and administrative weaknesses of the US COIN campaign which allowed the insurgency to rise and consolidate.

\section{Political Weakness and the Problem of Legitimacy}

The US intervention in Iraq was challenged on legal grounds and suffered from a problem of legitimacy from the very start. It was not approved by a UN Security Council Resolution (UNSC), whose permanent members, France, Russia and China, were opposed to the intervention. Moreover, many US allies in the region and around the world, including Germany, Turkey, Canada, Saudi Arabia and Jordan, opposed the invasion. In an interview with BBC News on 16 September 2004, the then UN Secretary General, Kofi Annan said that "[the war] is not in conformity with the UN Charter, from our point of view and from the Charter point of view it was illegal." ${ }^{7}$

The US President G.W. Bush announced that "our mission is clear, to disarm Iraq of weapons of mass destruction, to end Saddam Hussein's support for terrorism, and to free the Iraqi people." ${ }^{8}$ However, the US military failed to uncover any weapons of a mass destruction program, and even the US government was accused of manipulating intelligence to support the invasion despite knowing that such a program did not exist. On the other hand, not only did the intervention not reduce terrorism, it also changed the terrorists from thugs and extremists to freedom fighters in many people's eyes.

A counter-insurgency is primarily a political campaign to gain legitimacy and win over the population. While the insurgents have a superior cause, the counterinsurgents have the resources to provide security, governance and services to the population and gain their support. The political dimension of the Iraq war, however, was largely neglected and there was no plan for post-intervention stability operations after the defeat of Iraqi military and overthrow of Sad-

6 Galula, Counterinsurgency Warfare: Theory and Practice, 17.

7 Kofi Annan, "Excerpts: Annan Interview," BBC News, September 16, 2004, accessed March 20, 2016, http://news.bbc.co.uk/2/hi/middle_east/3661640.stm.

8 George W. Bush, Radio Address, March 22, 2003, White House Archives, accessed March 20, 2016, http://georgewbush-whitehouse.archives.gov/news/releases/ 2003/03/20030322.html. 
dam Hussain regime. Neither was there a political road map for the country's political future before the intervention. As was noted by Anthony Cordesman, "the US government failed to draft a serious or effective plan for phase 4 of the war: the period of conflict termination and creation of an effective nation building office." $^{9}$

Thus the US legitimacy among the Iraqi population was further undermined when the fall of Baghdad was followed by widespread disorder, looting and lawlessness. The US Secretary of Defense, Donald Rumsfeld was criticized for the chaos following the intervention, whose response was illustrative of the severity of the problem: "Freedom's untidy, and free people are free to make mistakes and commit crimes and do bad things. They're also free to live their lives and do wonderful things. And that's what's going to happen here." 10

The lack of coordination between the US Department of Defense (DOD) and Department of State (DOS) in the post intervention period further added to the problem leading to a window of opportunity being lost to win over credibility and support of the population. ${ }^{11}$

\section{Poor Policy Decisions: De-Ba'athification and Disbanding the Iraqi Army}

Instead of winning the hearts and minds and support of the population, some decisions of the Coalition Provisional Authority (CPA) in the initial phase of intervention were counterproductive and instead strengthened the insurgency. Two of the most ill-fated and problematic policy decisions which injected life and blood to the insurgency and whose effects continue to the present was the de-Ba'athification of Iraqi society and the dissolution of Iraqi security forces.

The very first Order issued by Paul Bremer, head of the CPA, was about deBa'athification of Iraqi society. According to that order, members of Ba'ath Party were dismissed from their positions and banned from future employment in government. In addition, individuals holding positions at ministries or other government institutions, including universities and hospitals were to be interviewed and removed from their jobs if found to be linked to Ba'ath Party. ${ }^{12}$ This practically targeted the Iraqi Sunni community who made up the bulk of the Ba'ath party membership and senior government positions, leaving them no option but to fight back.

9 Anthony H. Cordesman, "Iraq: Too uncertain to call" (Centre for Strategic and International Studies, 2003), 2.

10 Sean Loughlin, "Rumsfeld on looting in Iraq: 'Stuff happens,'” CNN, April 12, 2003, accessed March 20, 2016, http://edition.cnn.com/2003/US/04/11/sprj.irq.pentagon.

11 Bruce Hoffman, "Insurgency and Counterinsurgency in Iraq," Studies in Conflict \& Terrorism 29, no. 2 (2006): 103-121, quote on pages 2-3.

12 Paul L. Bremer, “Coalition Provisional Authority Order Number 1: De-Ba'athification of Iraqi Society" (Coalition Provisional Authority, 2003), accessed March 1, 2016, http://www.iraqcoalition.org/regulations/20030516_CPAORD_1_DeBa_athification_ of_Iraqi_Society_.pdf. 
The second CPA order issued on 23 May, 2003, dissolved the Iraqi army and other security institutions and cancelled "any military or other rank, title, or status granted to a former employee or functionary of a Dissolved Entity by the former regime." ${ }^{13}$ This left some 230,000 former Iraqi military officers and NonCommissioned Officers (NCO's) on the streets, explicitly ruling out any hope for a future employment or career. Well-trained and armed, many of them joined the insurgency led by al-Zarqawi or other insurgent groups. Since then, Ba'athists and former army officers have formed the backbone of the insurgency throughout the years. In 2006, 99 out of 200 generals of the old Iraqi Army "were probably active in the insurgency." ${ }^{14}$ When Abu Bakr al-Baghdadi took over the leadership of the group, he started an aggressive campaign in 2010 to recruit former Ba'athists and army officers to revitalize the weakened insurgency. For instance, 34 out of 42 senior $A Q I$ leaders were killed in a very short time, and al-Baghdadi used this opportunity to fill those vacancies by former Ba'athists and military officers, in what was seen as "Iraqization" of IS. ${ }^{15}$

According to Brig. Gen. Hassan Dulaimi, a former intelligence officer in the old Iraqi Army, "The people in charge of military operations in the Islamic State were the best officers in the former Iraqi army, and that is why the Islamic State beats us in intelligence and on the battlefield." ${ }^{16}$ According to Sajad Jiyad, a senior analyst and researcher at the al-Bayan Centre for Studies \& Planning in Baghdad, more than 25 of out of 40 most prominent leaders in 2014-15 were former Ba'ath Party members or military officers. He believes "ISIL, as an organization, would not exist without former Baathists." ${ }^{17}$

Many US military and civilian leaders realized the negative impacts of deBa'athification and dissolution of Iraqi security institutions over time, but they could not reverse or stop the process. A de-Ba'athification commission continued to function and played a role in disqualification of many important Sunni leaders in the 2010 parliamentary elections. Prime Minister Maliki arrested a

13 Paul L. Bremer, "Coalition Provisional Authority Order Number 2: Dissolution of Entities," Baghdad, May 23, 2003, accessed March 1, 2016, www.iraqcoalition.org/ regulations/20030823_CPAORD_2_Dissolution_of_Entities_with_Annex_A.pdf.

14 Bruce R. Pirnie and Edward O'Connell, Counterinsurgency in Iraq (2003-2006), Volume 2 (Santa Monica, CA: Rand Corporation, 2008), 26.

15 Michael Weiss and Hassan Hassan, ISIS: Inside the Army of Terror (New York: Simon \& Schuster, 2015), 120-21.

16 Liz Sly, "The hidden hand behind the Islamic State militants? Saddam Hussein's," Washington Post, April 4, 2015, accessed February 14, 2016, https://www.washingtonpost.com/world/middle_east/the-hidden-hand-behind-theislamic-state-militants-saddam-husseins/2015/04/04/aa97676c-cc32-11e4-87304f473416e759_story.html.

17 Davide Mastracci, "How the catastrophic American decision to disband Saddam's military helped fuel the rise of ISIL," National Post, May 23, 2015, accessed February 14, 2016, http://news.nationalpost.com/news/world/how-the-catastrophic-americandecision-to-disband-saddams-military-helped-fuel-the-rise-of-isil. 
large number of alleged Ba'athists even as late as $2011 .^{18}$ Some Ba'athist and former army officers had joined the Awakening Movement and fought AlQaeda during the "surge" in 2007. However, once the US troops left, the Iraqi government abandoned the Awakening Movement and started harassing its leaders who were once again left with no option but to join IS. ${ }^{19}$

\section{Military Weakness: Inability to Protect the Population}

The US intervention in Iraq not only suffered from political legitimacy and miscalculations but also from insufficient resources and poor counterinsurgency efforts in the early stages. While known to be the best conventional military with unprecedented advanced technology and firepower, the US army was not ready for countering an insurgency. It "went into Iraq in March 2003 without any of the doctrine, training, or other preparations." ${ }^{20}$ Lessons learned in Vietnam had not been internalized and were discarded. And the Bush administration was not ready to commit the required number of troops to maintain security and order in post-Saddam Iraq.

The US Army and Marines Counterinsurgency Field Manual suggests a minimum of 20 troops per thousand population for a successful COIN campaign, as has been proposed in COIN literature elsewhere. ${ }^{21}$ For example, the British deployed troops at a ratio of 20 counterinsurgents per 1,000 population in Northern Ireland and Malaya campaigns. Similarly, NATO started its multinational operation in Bosnia with a ratio of more than 20 troops per 1000 population. $^{22}$ According to this ratio, with more than 30 million population, about 600,000 troops would have been required to defeat the insurgency in Iraq. However, in early 2004 there were 115,000 US troops deployed to Iraq and it did not exceed 171,000 (182,000 with British forces) even at the peak of the "surge."

Insufficient resources meant that the US forces were not able to protect the population and gain their support, the key to success according to counterinsurgency theories. It also meant that the US military commanders were not willing to confront the Shia militias and trouble makers, especially Muqtada alSadr and his Mahdi Army, which contributed to sectarian problems and loss of

18 W. Andrew Terrill, Lessons of the Iraqi De-Ba'athification Program for Iraq's Future and the Arab Revolutions (Carlisle, PA: U.S. Army War College, Strategic Studies Institute, May 2012), accessed April 12, 2016, http://www.dtic.mil/dtic/tr/fulltext/u2/ a560673.pdf, p. $x$.

19 Sly, "The hidden hand behind the Islamic State militants?"

20 Brian Burton and John Nagl, "Learning as we go: the US army adapts to counterinsurgency in Iraq, July 2004-December 2006," Small Wars \& Insurgencies 19, no. 3 (September 2008): 303-27.

21 John A. Nagl, et al., The US Army/Marine Corps Counterinsurgency Field Manual (University of Chicago Press, 2008), 23.

22 James T. Quinlivan, "Burden of Victory: The Painful Arithmetic of Stability Operations," Rand Review 27, no. 2 (2003): 28-29. 
credibility for both the US and Iraqi governments. Moreover, insufficient troops and resources rendered the US troops and Iraqi government unable to provide rule of law and basic services - means that could have earned them legitimacy and support of the populace.

In short, weakness of the counterinsurgents, in this case the US and Iraqi governments, including weak legitimacy, problematic policy decisions, lack of a COIN doctrine and insufficient resources and troops led to a deterioration of security and an exponential increase of violence in Iraq. The number of attacks by insurgents increased to 26,496 in 2004 and to 34,131 in 2005. In late 2005, the number of improvised explosive devices (IED) attacks reached to about 1,800 per month. Al-Zarqawi was targeting the Shias indiscriminately to provoke sectarian conflict while the Shia-dominated security forces were responsible for incidents of torture and extra-judicial killings of the Sunnis and suspected insurgents. With the bombing of the Samarra Shrine, which is the most sacred shrine among the Shias, in February 2006, the insurgency turned to a large scale sectarian violent conflict. The Shia death squads entered in the Sunni areas, indiscriminately killing civilians while the Sunni extremists continued to target Shia civilians by suicide bombings, increasing the civilian casualties to $34,000 .^{23}$

\section{The "Surge:" and the Awakening Movement}

As the insurgency and violence continued to intensify, the US military continued to learn and adapt. When General Petraeus was appointed as the top American command in Iraq, he helped publish the US Army and Marine Corps Counterinsurgency Field Manual (FM 3-24). In January 2007, the US President, G.W. Bush, ordered the deployment of more than 20,000 additional troops to Iraq which was termed as the "Surge," while at the same time commanders of on the ground changed their counterinsurgency strategy.

According to Australian COIN expert, David Kilcullen, "the surge is not the strategy - the switch to population security and a residential, high-force-density, long-term approach is what matters here." ${ }^{24}$ The same can be concluded from President Bush's State of the Union address in January 2007, when he outlined the purpose of the surge as: "Our troops will have a well-defined mission: to help Iraqis clear and secure neighbourhoods, to help them protect the local population, and to help ensure that the Iraqi forces left behind are capable of providing the security that Baghdad needs." ${ }^{25}$ Major General Joseph Fil, commander of Multi-National Division - Baghdad, who oversaw the implemen-

23 Burton and Nagl, "Learning as we go: the US army adapts to counterinsurgency in Iraq."

24 David Kilcullen, "Don't Confuse the 'Surge' with the Strategy," Small Wars Journal (January 2007), accessed March 5, 2016, http://smallwarsjournal.com/blog/dontconfuse-the-surge-with-the-strategy.

25 Ibid. 
tation of Baghdad Security Plan in February 2007, described the objectives of the plan as: "through this operation, the government of Iraq is seeking to show the Iraqi people and the international community that it is able to protect all its citizens, regardless of sect or ethnicity." ${ }^{26}$ At the same time, the US commanders worked with Sunni tribes and the general population as part of the Sahwa or Awakening Movement, which succeeded in turning them against AQI until the US troops withdrew from Iraq.

It could be argued that the change in strategy which was aimed at protecting and gaining the support of the population worked. From its highest point in late 2006, by November 2007, violence and insurgents' attacks had dropped to their lowest levels since 2004. While there were 300 attacks in al-Anbar province per week prior to the "surge," their number had dropped to about 20 per week in late 2007. There was a dramatic improvement in Baghdad security as well. The civilian deaths which reached 3,000 in December 2006 was lowered by $70 \%$ by November 2007 . The number of attacks was down by $60 \%$, and sectarian violence had plummeted by $90 \%{ }^{27}$

A significant part of the reduction in violence could be attributed to efforts at fixing the political challenges, including the inclusiveness and legitimacy of the Iraqi government. The Sunni Awakening or Sahwa Movement, a US supported program to arm the Sunni tribes to defend themselves, was very effective in turning them against Al-Qaeda and consequently reducing violence and weakening of the insurgency significantly.

\section{The US Withdrawal and Return of the Insurgents}

While the "surge" brought significant resources and the right population-centric COIN strategy, which succeeded in reducing the violence and weakening the insurgency, support for the war in the US had plummeted to its lowest point since the start of intervention. From the political perspective, it was difficult to commit to a long term presence of US troops in the country. At the same time, the Iraqi government had little interest to extend the presence of US troops in Iraq. A US-Iraq Status of Force Agreement (SOFA) was signed by President Bush and Iraqi Prime Minister Maliki in 2008, according to which all US troops withdrew from Iraq by the end of December 2011.

Although there have been disagreements, it could be argued that there were mainly two plausible contributing factors for improvement in security in Iraq in 2007. First, the "surge" and the application of a population centric counterinsurgency enabled the American and Iraqi troops to protect the population from the insurgents, who could no longer terrorize them into cooperation. The

26 Kimberly Kagan, Iraq Report (Washington, D.C.: The Institute for the Study of War, 2007).

27 Raymond T. Odierno, "The Surge in Iraq: One Year Later," Lecture \#1068 on National Security and Defense (Heritage Foundation, 13 March 2008), accessed March 12, 2016, http://www.heritage.org/research/lecture/the-surge-in-iraq-one-year-later. 
increase in violence and casualties of US and Iraqi forces in the initial stages of the "surge" shows that insurgents and Shia militias did not just decide to stop fighting - rather the new strategy severely restricted their abilities to continue to fight. Second, the combined effects of Sahwa Movement and the protection of the population removed the sectarian security dilemma faced by the Sunnis. As a result, the Sunni communities turned against AQI and other extremists, leading to a significant weakening of the insurgency. However, given that the Iraqi government could not maintain the support of the population due to its weaknesses and sectarian policies, the premature withdrawal of US troops allowed a revival of insurgency which eventually evolved into IS.

\section{Administrative Weakness: Inability to Provide Services}

According to COIN theories, the population is the center of gravity and its support - the key to success for either side. In addition to political and military measures, the counterinsurgents aim to gain this support through delivering administrative services such as education, jobs, healthcare etc. In post-Saddam Iraq, however, the Iraqi government was not able to provide basic services to the population properly. De-Ba'athification had removed many skilled and experienced individuals from different ministries, crippling the government functioning. On the other hand, De-Ba'athification and dissolution of Iraqi security institutions had also left hundreds of thousands Iraqis, including "tens of thousands" of schools teachers unemployed. ${ }^{28}$ All this presented significant administrative challenges to the Iraqi government and curtailed its ability to provide services and gain support of the people.

\section{Indoctrination and Networking in Detention Facilities}

The "surge" and the consequent shift to a population-centric strategy meant more combat and kinetic operations, leading to the arrest of thousands of insurgents who were detained in US run detention facilities. These detention facilities were used by ISI as "Jihadi Universities" for recruiting, indoctrinating, networking and transferring skills among the fighters. One of the major detention centers was Camp Bucca, which housed 26,000 insurgents in 2007, and funneled some 100,000 detainees including many of the top leaders of IS. ${ }^{29}$

Besides Abu Bakr al-Baghdadi who spent five years in Camp Bucca, nine other member of IS senior leadership, including al-Baghdadi's deputy, Abu Muslim al-Turkmani, IS senior military leader Haji Bakr (who was killed), and the leader of foreign fighters Abu Qasim served time in the facility. Given that insurgents could not get together for fear of being targeted by American troops, Camp Bucca was a great opportunity for them to stay together for months and in some cases years to develop their plans. Many of the people

\footnotetext{
28 Andrew Terrill, Lessons of the Iraqi De-Ba'athification Program for Iraq's Future and the Arab Revolutions, 24.

29 Weiss and Hassan, ISIS: Inside the Army of Terror, 83.
} 
who served in this Camp had some links to insurgents, which was why they were there in the first place. However, even accidental guerrillas or former Ba'athists who had nothing in common with IS ideology were turned into hardliners while serving there with many radical ideologues.

According to Richard Barret, Camp Bucca facilitated and strengthened the alliance between members of $\mathrm{AQI}$ and ex-Ba'athists. Many Ba'athists whose time in prison overlapped with Abu-Bakr al-Baghdadi became senior leaders of IS. ${ }^{31}$ Over the years, inmates who were released went back to join the insurgency with much better skills and wider network of contacts. After the prison was transferred to Iraqi authorities following the withdrawal of US troops, the remaining inmates were released, which had a significant negative consequence for the insurgency in Iraq and the evolution of IS. ${ }^{32}$

In short, the years in Camp Bucca were formative for IS. The radical Islamists who provided the ideology intermingled and cemented their alliance with Ba'athists who had the military planning, strategic and governance skills. This was something that eventually changed IS into a powerful and deadly organization, a pseudo-state which has out-governed many of the Syrian rebel groups and perhaps even the Syrian and Iraqi governments.

To sum up, the US intervention in Iraq in 2003 contributed to the rise and consolidation of IS by serving as a strategic cause for the insurgency, while ineffective US and Iraqi government COIN strategy and insufficient resources allowed the insurgency to expand. Although the US troops' "surge" and change of the US COIN strategy succeeded in weakening the insurgency, the lack of a long-term commitment and the premature withdrawal of US troops led to a revival of the insurgents. And finally, poor management of US-run detention facilities played an important role in the rise and consolidation of the Islamic State by facilitating networking and indoctrination of insurgents in custody.

\section{Sectarian Conflict and the Rise of Islamic State}

Sectarian or ethnic conflict, which is referred to the conflict between Shias and Sunnis in Iraq and the region is another important factor that contributed to the rise and consolidation of IS. To analyze this hypothesis the paper will be relying on theories of ethnic conflict. Although technically ethnicity and religious sects are different, for the purposes of this article the two terms will be

30 Terrence McCoy, "Camp Bucca: The US prison that became the birthplace of Isis," Independent, November 4, 2014, accessed April 12, 2016, www.independent.co.uk/ news/world/middle-east/camp-bucca-the-us-prison-that-became-the-birthplace-ofisis-9838905.html.

31 Richard Barrett, The Islamic State, The Soufan Group Report, November 2014, accessed April 5, 2016, http://soufangroup.com/wp-content/uploads/2014/10/TSGThe-Islamic-State-Nov14.pdf.

32 Cockburn, The Rise of Islamic State: ISIS and the New Sunni revolution, 88. 
used synonymously, and Shiism and Sunnism will be used as two separate identities similar to ethnicity.

\section{Historical Background of the Sectarian Conflict}

Traditionally, Sunnis have dominated political power in the Islamic world. Ever since the Islamic Revolution in Iran, Shias have continued to increase their power and influence in different countries, causing concerns among the Sunni regimes in the Middle East. The Iran-Syria alliance strengthened the position of the two countries against their Sunni dominated neighbors. ${ }^{33}$ The creation of Hezbollah and its emergence as a strong player in Lebanon and in resistance against Israel further boosted the confidence of Shias in the region and beyond. Finally, the fall of Saddam's regime and its replacement by a Shia dominated government changed the balance of power in this traditionally Sunni dominated region, intensifying concerns and anxiety, which has been expressed by Sunni leaders.

In late 2004, King Abdullah of Jordan expressed concern that if the Shias dominate the post-intervention Iraqi government, "a new crescent of dominant Shia movements or governments stretching from Iran into Iraq, Syria, and Lebanon could emerge ..." ${ }^{34}$ In September 2005, Saudi Foreign Minister, Saud bin Faisal, criticized the war in Iraq as "handover of Iraq to Iran" and expressed concern about Iranian influence among the Iraqi Shias. In a similar trend, in April 2006, Hosni Mobarak, the then President of Egypt criticized Iraqi and other countries' Shias for being more loyal to Iran than their own country. ${ }^{35}$

To counter the Iranian influence, the Saudis have attempted to proliferate their anti-Shia Wahhabi ideology by funding of mosques, madrasas and educational institutions throughout the world. ${ }^{36}$ Between 1982 and 2005, Saudi Arabia financed 210 Islamic centers, 1500 mosques, 202 Islamic faculties and 2000 schools around the world. In 2013, the country provided 35 billion USD funding for schools in South Asia which is home to around one billion of the world 1.6 billion Muslims. ${ }^{37}$ While this may be partly because Saudis believe in Wahhabism and therefore do so for religious purposes, one cannot disregard the fact that Shia-Sunni sectarian consideration also plays a part in this.

33 Vali Nasr, The Shia Revival: How Conflicts within Islam Will Shape the Future (New York: W.W. Norton \& Company, 2007).

34 Amir M. Haji-Yousefi, "Whose Agenda Is Served by the Idea of a Shia Crescent?" Alternatives: Turkish Journal of International Relations 8, no. 1 (Spring 2009): 11435.

35 Ibid.

${ }^{36}$ Nasr, The Shia Revival: How Conflicts within Islam Will Shape the Future.

37 Bouthaina Shaaban, "The Rise of ISIS and Other Extremist Groups: the role of the West and Regional Powers" The Canadian Charger, February 19, 2016, accessed April 12, 2016, http://www.thecanadiancharger.com/page.php?id=5\&a=1967. 
Thanks to generous funding, Saudi Wahhabi teaching and influence has spread throughout the world. This is the ideology which provides intellectual foundation and inspiration for most of the militant extremist groups today. In Sami Moubayed's words, without Wahhabism "there would be no Saudi Arabia, no Islamic State in al-Raqqa today and no talk of al-Qaeda or ISIS." 38

\section{Sectarian Conflict in the Region and Support for IS}

The sectarian conflict in the region has benefited IS in two ways. First, it has led to generous funding for the insurgent groups, which has directly or indirectly benefited IS. Second, the sectarian support of the Sunni tribes for IS has strengthened the group against the Iraqi and Syrian governments. Moreover, sectarian motivated conflict in Syria led to weakening of the Assad regime, leaving a gap where IS could expand.

Sunni regimes in the region have been concerned about a potential uprising and insurgency among their Shia populations since the late 1970s. One could argue that one of the main reasons for Suddam's war against the nascent Islamic Republic of Iran was the fear of the export of the Shia revolution to Iraq. ${ }^{39}$ Given that Iraq is a Shia majority country, a security dilemma for Saddam may have been either to attack and destroy the Shia regime while it was weak or face a Shia revolution at home inspired or supported by the Islamic Republic of Iran. However, while Saddam did not succeed in overthrowing the Shia revolutionary regime, the balance of forces was such that Iran could not export its revolution to Iraq or to any other major Sunni dominated countries. Despite that, mutual suspicions between the Islamic Republic of Iran and Sunni countries continued.

Since the overthrow of Saddam which disturbed the sectarian balance of power, sectarian considerations in the region have helped funnel millions of dollars from the Sunni countries of the Gulf region to Islamic State. The Gulf countries and Turkey have directly or indirectly supported the Sunni insurgent groups in Syria, hoping to balance the replacement of Saddam's regime by a Shia government, with the replacement of al-Assad regime with a Sunni extremist group.

Saudi Arabia has continued to be a major source of funding for extremist groups worldwide. According to a cable from WikiLeaks, the US Secretary of State, Hillary Clinton wrote in December 2009 that "Saudi Arabia remains a critical financial support base for al-Qaeda [...] and other terrorist groups." In 2007, Stuart Levey, the US Under Secretary for Terrorism and Financial Traf-

38 Sami Moubayed, Under the Black Flag: At the Frontier of the New Jihad (I.B. Tauris, November 2015), 11.

39 Thom Workman, "The Social Origins of the Iran-Iraq War," CISS Working Paper \#5 (Downsview, Ontario: York University, Centre for International and Strategic Studies, 1991). 
ficking said in an interview: "if I could somehow snap my fingers and cut off the funding from one country, it would be Saudi Arabia." 40

In addition to direct government funding, these countries have turned a blind eye on funds flowing from wealthy individuals, charitable foundations and other networks to insurgent groups. In 2012-2013, bags of cash filled with millions of dollars were channeled to insurgents groups through Turkey on regular basis. In 2013 and 2014, IS received as much as 40 million USD from the gulf countries. $^{41}$ Given its problems with al-Assad regime, Turkey has had little interest to prevent flow of funds, arms and fighters to the insurgents in Syria.

\section{Sectarian Conflict in Iraq and the Rise of Islamic State}

The US intervention in Iraq and the fall of Saddam changed the political equation of the country. After years of suffering from discrimination and persecution, now the Shias were the rulers in the new democratic Iraq. They considered themselves entitled to it according to the principle of rule of majority, and were not ready to lose it at any cost. At the same time, de-Ba'athification and dissolution of the Iraqi army in practice meant deprivation of Sunnis from political power, something that was unacceptable for the Sunni community. As proposed by Lars-Eric Cederman, Andreas Wimmer and Brian Min, ethnic groups are more likely to fight if they have lost power recently. ${ }^{42}$ Thus this was a motivating factor for Sunnis to join the insurgents and fight the Shia-dominated government and its foreign supporters.

Another but perhaps more important factor for sectarian violence was a sectarian security dilemma which was created after the fall of Saddam. When an empire, state or central authority falls or becomes so weak that it cannot provide for order and security of its citizens, a security dilemma is created for ethnic or other identity groups. In such a situation, each group assumes responsibility for its own security, and tries to provide for it by acquiring arms or establishing its own ethnic army to defend itself. ${ }^{43}$ In Iraq, not only was such a sectarian security dilemma created due to the fall of Saddam and the subsequent dissolution of security institutions, but was also provoked and intensified by AQI.

Zarqawi, like many other Takfirists, had a violent contempt for the Shias but he was also "exploiting what was an incipient but real problem in Iraq's political

40 Moubayed, Under the Black Flag: At the Frontier of the New Jihad, 11-12.

41 Matthew Levitt, "Terrorist Financing and the Islamic State," Testimony submitted to the House Committee on Financial Services, November 13, 2014, Washington Institute, accessed March 29, 2016, www.washingtoninstitute.org/uploads/Documents/ testimony/LevittTestimony20141113.pdf

42 Lars-Erik Cederman, Andreas Wimmer, and Brian Min, "Why Do Ethnic Groups Rebel? New Data and Analysis," World Politics 62, no. 1 (January 2010): 87-119.

43 Michael E. Brown, ed., Ethnic Conflict and International Security (Princeton University Press, 1993), 103-10. 
evolution: namely the creeping takeover of state institutions by chauvinistic Shia politicians." ${ }^{44}$ With the fall of Saddam's regime, the dissolution of the old Iraqi Army and de-Ba'athification program, the Sunni community thought they were left at the mercy of Iranian supported Shia opponents. Zarqawi was trying to intensify this sectarian security dilemma and draw Sunnis to the insurgency. As his letter to Bin-Laden in 2004 illustrates, his intention was to spark a widespread sectarian violence in Iraq so that the Sunnis had no other option but to turn to AQI as their protector:

[by] targeting and hitting [Shia] in [their] religious, political, and military depth [to] provoke them to show the Sunnis their rabies and bare the teeth of the hidden rancor working in their breast. If we succeeded in dragging them into the arena of sectarian war, it will become possible to awaken the inattentive Sunnis as they feel imminent danger and annihilating death at the hands of these Sabeans. ${ }^{45}$

By 2006 Iraq was in the midst of a ruthless and violent sectarian conflict. The bombing of the Shia sacred Shrine of Samarra led to an unprecedented hike in sectarian violence where civilians of both Shia and Sunni communities were targeted by the death squads of the other side. Shia militias started moving into Sunni residential areas and killing hundreds in retaliation to the bombing of the shrine while the Sunni extremists targeted Shias by suicide bombings. Mass murders and abductions were the order of the day and bodies were thrown into the streets. The death toll reached to 34,000 in $2006 .{ }^{46}$ By the end of 2006, the Sunni community were pushed into a corner and believed that the only protector and savior against the brutal death in the hands of the Shia militias were the AQI and other Sunni extremist groups. ${ }^{47}$ As shown in the chart below, the total number of terrorist attacks exceeded 5,000 in November 2006. $^{48}$

It was at the peak of sectarian violence that the "surge" and Sahwa (or the Awakening Movement of the Sunnis), were implemented. The strategic aim of both was to protect the population and address the underlying sectarian security dilemma. Now the Sons of Iraq, a coalition of Iraqi tribes armed and financed by the US military, provided security to the Sunni communities. No longer dependent on Al-Qaeda for security against the Shia militia, the Sunni

44

45

46

48 Michael E. O'Hanlon and Jason H. Campbell, Iraq Index - Tracking Variables of Reconstruction \& Security in Post-Saddam Iraq, Brookings Institution Report (December 2008), accessed March 29, 2016, https://www.brookings.edu/wp-content/uploads/ 2016/07/index20081218.pdf. 


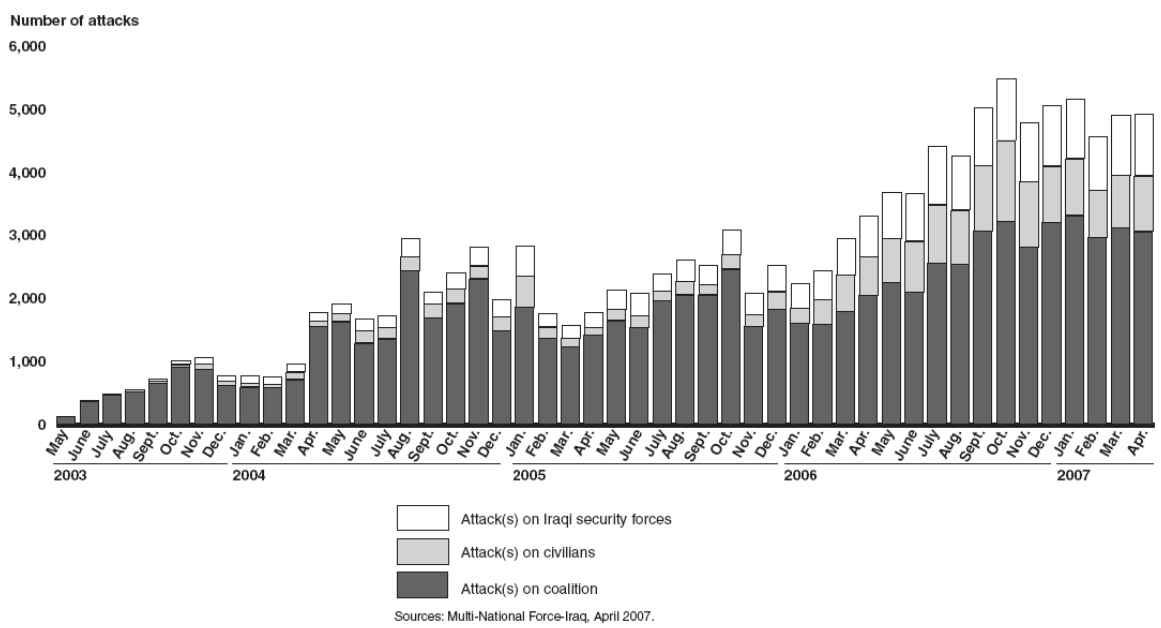

Figure 1: Enemy-initiated attacks against the coalition and its partners.

tribes turned against it, leading to a significant reduction in violence and weakening of the insurgency.

However, once the US troops left and Awakening Movement was abandoned by Iraqi government, the sectarian security dilemma intensified once again, pushing the Sunnis towards the IS. Abu Bakr al-Baghdadi used the same strategy of provoking a sectarian security dilemma by using the "sectarian-existential grammar" of Zarqawi, while presenting itself as the protector and defender of the Sunnis in Iraq and Syria. ${ }^{49}$ The terrorist group continued to slaughter Iraqi civilians as well as Iraqi security forces on a sectarian basis. In June 2014, IS executed 1,700 Shia soldiers after occupying Mosul. ${ }^{50}$ Similarly, after capturing Tikrit, IS fighters divided the surrendered soldiers into two groups of Shias and Sunnis, and the Shias were all killed. These factors of course intensified sectarian conflicts with serious consequences for the region and the world.

\section{Sectarian Policies of Prime Minister Maliki and the Return of the Insurgents}

With the decrease of the US presence and influence in Iraq, the Maliki government became increasingly sectarian. The Awakening Movement was gradually put to an end and its leaders were harassed by the Shia dominant security forces. The situation in Diyala province was the most problematic. After the

49 Weiss and Hassan, ISIS: Inside the Army of Terror, 29.

50 Simon Tomlinson and Amy White, Mail Online, 13 June 2014, accessed August 4, 2016, www.dailymail.co.uk/news/article-2656905/ISIS-jihadists-seize-two-towns-bearBaghdad-U-S-tanks-helicopters-stolen-fleeing-western-trained-Iraqi-forces.html. 
Prime Minister dispatched Iraqi Special Operations Forces to arrest the President of Diyala University and a local council man, which resulted in the death of governor's press secretary, the situation in the province went out of control. ${ }^{51}$

In Anbar province, Colonel Saad Abbas Mohammad, a commander of 3,000 Sons of Iraq, was the target of about 25 assassination attempts according to his own account. A program designed by the United States to transition about 30,000 Awakening Movement volunteers to state employment was not realized. Members of the Awakening Movement started to return to the insurgency now led by a more ambitious leader, Abu Bakr al-Baghdadi. According to Mullah Nadim Jibouri, in 201040 percent of AQI was composed of former Sons of Iraq who had defected due to fissures re-emerging between the government and Sunni tribes. ${ }^{52}$

Whilst one could ascertain that Maliki was playing the sectarian card in order to strengthen his support base among the Shia community for election purposes, the consequences for the country were destructive. In 2010 parliamentary elections Mr. Maliki won two seats less than his rival, Ayad Allawi's block. Nevertheless he managed to form the government with Iranian support and intervention. Henceforth, he became even more sectarian. In December 2011, he ordered the arrest of two of the most senior Sunni leaders, Rafi Al-Issawi, the Finance Minister, and Tariq al-Hashimi, the Vice President of Iraq on charges of terrorism. Mr. Hashimi fled to Kurdistan and was sentenced to death in absentia. These and other sectarian policies by Maliki led to demonstrations in Sunni-dominated areas of Iraq. On April 2013, the Iraqi Army stormed a peace camp at Hawijah, west of Kirkuk, killing more than fifty peaceful Sunnis. This incident and other underlying grievances turned the protests into an insurgency and widespread violence throughout Iraq, leading to al-Qaeda style attacks on Shia sites as well as attacks on Sunni mosques. ${ }^{53}$

While Mr. Maliki's fear-mongering sectarian political campaign which was built around a Sunni counter-revolution helped him to succeed in 2014 elections, it helped Baghdadi too. A little more than a year following the start of widespread Sunni protest, during which Maliki refused to give any concessions, IS was at the outskirts of Baghdad. By June 2014, with the help of local Sunnis, IS had captured Sunni dominated provinces of Nineveh, Salahuddin and parts of Diyala, and proclaimed its Caliphate. ${ }^{54}$

\section{Conclusion}

This research paper examined the extent to which both the US intervention in Iraq in 2003 and sectarian conflict in the country and the region contributed to

\footnotetext{
51 Weiss and Hassan, ISIS: Inside the Army of Terror, 90.

52 Ibid., 91.

53 Ibid., 96-97.

54 Cockburn, The Rise of Islamic State: ISIS and the New Sunni Revolution, 48.
} 
the rise and consolidation of IS. Based on the above analysis, both the US intervention in 2003 and ethnic conflict in Iraq and the region did contribute to the rise and consolidation of IS. While the US intervention contributed to the rise, popularity and strengthening of the insurgency, sectarian conflict contributed to the consolidation and sustainment of the group.

It was argued that the US intervention in Iraq and its aftermath contributed to the rise and consolidation of IS in the following ways: First, it created a strategic cause for mobilization and popularity of the insurgency that eventually evolved to IS. Second, weakness of the counterinsurgents, deemed as a prerequisite of a successful insurgency, allowed a strengthening of the insurgency. Political weakness of counterinsurgents included the weak legitimacy, the lack of a post-intervention plan and poor policy decisions such as de-Ba'athification and disbanding of the Iraqi army. Military weakness referred to the challenges of insufficient troops and the lack of a COIN doctrine in the initial phase of the intervention.

While the US military adapted its strategy and extra troops were deployed, which succeeded in reducing violence and weakening the insurgency, the lack of a long-term commitment from the US, unwelcoming attitude of Iraqi government and premature withdrawal of US troops led to a revival of the insurgency. Finally, administrative weakness, including inability to provide services to the people, limited government's ability to win over the population. Further it was argued that the US-run detention facilities served as Jihadi universities for indoctrination of fighters and networking among senior AQI leaders who, later on, assumed leadership responsibilities in the Islamic State.

Sectarian conflict in Iraq and the region, it was argued, contributed to the rise and consolidation of IS in the following ways. First, a sectarian security dilemma in the region following the Islamic revolution of Iran prompted Saudi Arabia's decision to fund the proliferation of Salafism/Wahhabism - an ideology that inspires extremist groups and provides the intellectual foundations for IS. Secondly, the overthrow of Saddam further intensified the sectarian security dilemma and funding from Saudi Arabia and its allies to Sunni insurgent groups to balance the shift of power to Shias in the region. The resultant continuation of conflict in Syria enabled IS to capture large swaths of territory and declare alRaqqa its capital. Finally, sectarian policies of Prime Minister Maliki and exclusion of Iraqi Sunni communities from power led to their support for IS, enhancing its capabilities to capture Sunni-dominated provinces in Iraq and eventually proclaim its Caliphate.

There are a number of lessons learned and policy implications that may be drawn from this analysis. The Islamic State is a very sophisticated political, military and ideological terrorist group that has used the sectarian conflict and external intervention to mobilize fighters and justify its atrocities. To defeat this group, the right political solution, a strong will and long-term commitment will be required. Firstly, a political solution which could address the security dilemma as well as the political, economic and religious rights of Sunni communi- 
ties in Iraq and Syria is a precondition for the defeat of the terrorist group. Secondly, a population-centric counterinsurgency strategy which could clear the territories of IS and keep the terrorists out by protecting the population and providing them security will be required over a long period of time to succeed. Thirdly, a regional agreement which addresses the security concerns of the main regional players such as Iran, Saudi Arabia and Turkey is needed for longterm security and stability in the region.

Another lesson learned is that external intervention creates a strategic cause for mobilization and may strengthen insurgencies. COIN campaigns require long-term commitment and considerable resources, which is oftentimes difficult to make or put in place. Therefore, it is better not to intervene in the first place where possible. However, wherever inevitable, the intervention should be well-planned and well-resourced with a legitimacy and long-term commitment to convince the people and insurgents that the government will eventually win. As the "surge" and some other cases of intervention such as Northern Ireland, Malaya and NATO intervention in Bosnia showed, a wellplanned and resourced counterinsurgency campaign with long-term commitment could in fact succeed in stabilizing the situation and defeating the insurgency.

\section{About the author}

Abdul Basir Yosufi is the General Director for International Cooperation at Afghanistan Ministry of Interior, where he has previously worked as a Senior Policy Advisor and Policy Analyst since 2010. Before joining the government, he worked in private and non-governmental organizations. He received his Master of Advance Studies (MAS) in European and International Security from GCSP and University of Geneva in 2016 as well as a Master of Science in Foreign Service from Georgetown University School of Foreign Service in 2010. He completed his Bachelor of Arts in Political Science from Delhi University in 2006. He has received several scholarships and awards including Fulbright scholarship, Georgetown SFS Dean's Award for Academic Excellence and GCSP/University of Geneva MAS award for the Most Outstanding Research Paper. He speaks Persian, Pashto, English, Urdu, Hindi and some Arabic. His research interests are Security issues in South Asia, Counter-terrorism Counter-insurgency and Security Sector Reform. 